\title{
Teaching English as a Global Language in Smart Classrooms with PowerPoint Presentation
}

\author{
Abraham Oommen ${ }^{1}$ \\ ${ }^{1}$ Instructor, PYP, Jazan University, Gizan, Kingdom of Saudi Arabia \\ ${ }^{1}$ Research Scholar, Singhania University, Pacheri Bari, (Raj), India \\ Correspondence: Abraham Oommen, Elankathil Jolly Villa, Nangiyar Kulangara P.O., Alleppey Dist., Kerala \\ State, India- Pin: 690 513. Tel: 91-90-4883-2469. E-mail: abraham_elankathil@yahoo.com
}

\author{
Received: September 2, 2012 Accepted: September 17, 2012 Online Published: October 19, 2012 \\ doi:10.5539/elt.v5n12p54 URL: http://dx.doi.org/10.5539/elt.v5n12p54
}

\begin{abstract}
The current study, as part of an ongoing investigation to examine teacher perceptions about the teaching of English as a global language at the tertiary level education, aims at examining learner perceptions about PowerPoint presentations used in English classroom instruction for enhancement and integration of four language skills and effective use of PowerPoint presentation as a teaching technique in smart classroom settings. A classroom action research and a questionnaire survey were conducted in a class consisting of 50 learners of Preparatory Year English Programme at Jazan University, Saudi Arabia. The results showed that learners preferred PowerPoint Presentations over traditional methods of lecture delivery and had positive attitudes towards PowerPoint presentations and lecturers who use them in their lessons. The result of this study conforms to previous studies to find the efficacy of PowerPoint presentations in university classroom instruction.
\end{abstract}

Keywords: global English, global village, smart classroom, PowerPoint presentation, learner perceptions

\section{Introduction}

Today the new technologies have transformed the world into a 'global village'. It is increasingly becoming clear that the global village would need a global lingua franca and English has emerged as the preferred language for global communication. Whereas languages have traditionally been taught from the view point of their cultures, we will now have to think of new techniques and materials so that global language learners can meet the challenges of the emerging global civilization and use the global language for their diverse needs.

In this scenario, it is obvious that teaching of this language based merely on the literary texts would not be appropriate. This is clear from the fact that most learners in majority of the countries, where English has traditionally been taught as a second or foreign language, find no relevance for the formal traditional class room teaching of English. The use of technological tools such as PCs, laptops, interactive smart board, over head projector, internet or mobiles in the classroom for instructional delivery has become very common and it has been found very effective. The smart classroom concept is the modern buzz word for school and college classrooms around the world which are in a process of transition from traditional to technology supported classroom instruction. The Smart Classroom integrates voice-recognition, computer-vision, and other technologies to integrate a tele-education experience with a real classroom experience.

Microsoft PowerPoint is a type of presentation software developed by Microsoft. It is one example of a technology that migrated from business and industry to education. It was first adopted by business executives and sales people who used it to give reports at meetings and presentations to clients. It's capability to demonstrate and clarify information became evident and it began to make its way into education. It allows one to show colored text and images with simple animation and sound. PowerPoint is an effective pedagogical tool in the classroom. PowerPoint presentations can be used in the classroom for initial teaching, for student projects, for practice and drilling, for games, for reviews, and for tests. This format is attractive to learners, and it appeals to learners' diverse learning styles, such as visual, auditory, kinesthetic, and creative by employing multimedia methods, such as sounds, images, color, action, design, and so on. Therefore, it is believed that Power Point presentations can improve the efficiency of English language classroom instruction. In addition, they can help teachers organize their thoughts and present their information in an orderly, attractive manner and learners to 
better understand the instruction of the teacher.

\section{Literature Review}

Today the English language classrooms have become smarter by the use of document cameras, dedicated computer projection systems and interactive whiteboards. An interactive whiteboard (IWB) is a large interactive display that connects to a computer projector. A projector projects the computer's desktop onto the board's surface where users control the computer using a pen, finger, stylus, or other device. Such systems allow users to make animated, interactive presentations with movement and video. Microsoft PowerPoint is such a software presentation technique that adds color, images, sound, animation, and hyperlinks to other documents, including Web documents.

\subsection{Positive Aspects of PowerPoint Presentations}

While PowerPoint presentations help teachers improve teaching, they also help learners absorb teachers' messages. Szaboa and Hastings (2000) hold that PowerPoint based classroom instruction helps learners focus attention and reduce distraction and observe that learners want PowerPoint presentations to be adopted in English language classroom instruction. Cashman and Shelly (2000) find that learners learn most effectively when their five senses are involved. The PowerPoint presentations appeal to learners' diverse learning styles, such as visual, auditory, kinesthetic, and creative by employing multimedia methods, such as sounds, images, color, action, design, and so on.

Microsoft PowerPoint is user friendly software which allows the integration of visuals and sounds. Schcolnik and Kol (1999) confirm that PowerPoint is a tool that allows learners to experience a world of real language opportunity. The use of this presentation software in a friendly, non-threatening classroom atmosphere encourages the integration of all four skills. Fisher (2003) explains that PowerPoint "can be used for initial teaching, for practice and drilling, for games, for reviews, and for tests." However, Towndrow and Vallance (2004: 109) argue for the necessity of organizing PowerPoint presentations based on a proper lesson outline that specifies clear and achievable language learning objectives. The show should support the design of language learning tasks which are not context-free and stand-alone exercises.

Catherina (2006) indicates that learners think PowerPoint based lectures are more interesting than traditional lectures (p. 4). According to Gaskins (1984) PowerPoint presentations improves effectiveness of presentation and improves clarity of complex material. Roblyer (2003) indicates that highly effective use of PowerPoint presentation helps learners to attend to and retain much of what they see on these slideshows (p. 179). Moreover, Fisher (1998) reports that student scores on tests are even improved with PowerPoint in classroom instruction as opposed to traditional chalk-walk and talk lectures.

Another important benefit of PowerPoint presentations for the instructors, according to Lanius, C. (2004) is that instructors can have face to face communication with learners contrary to the conventional chalk board teaching where instructors often face the chalkboard with their back to the class. Then, the format of creating a title and bullet points on a PowerPoint slide helps learners identify main ideas and their supporting details and there by helps learners structure their thinking. Further, the strength of PowerPoint is its ability to allow an instructor to import graphics, audio, quotes, and music or to link to simulations or Web pages and thus create an enriching learning experience.

Miltenoff (2003) indicates that PowerPoint can be used as a multimedia and interactive tool. Pictures, animation, sound effects, and music can greatly enhance the quality of the presentation. It is much easier to use attractive fonts, photos, clipart, tables, and graphs in PowerPoint. Instructors can use PowerPoint presentations to enhance the effectiveness of classroom instruction in many ways and in every subject area. Teachers can modify lessons and use them over and over again. Therefore, teachers save time on handing out instructional material, writing on blackboard, repeated speech and so on.

\subsection{Criticism on PowerPoint Presentations}

Although PowerPoint presentations are found to be effective in English language teaching, they pose some problems too. First, Voss, D. (2004) thinks learners feel ignored in the classroom when the instructor is focusing on the presentation and not paying attention to the class. Instead of interacting with learners during the class, the instructor in most cases is transfixed to the podium clicking the mouse all the time because of the need to advance to the next slide and unable to move across the room giving individual attention to learners. Also it happens that instructors too often focus on the technical aspects of the presentation rather than on the information being presented.

Second, Tufte, E. (2003) criticizes PowerPoint presentations by saying that merely flashing words or images on 
the slides won't make the content relevant if they are not on point. The audience gradually gets bored of the presentation if the content is not appropriately supported and enhanced. According to Keefe, D. D. and Willett, J.D. (2004), classroom instruction should be driven by the curriculum and appropriate content and not by the lavish use of technology. Further, McDonald, K. (2004) argues that focusing on graphics, animations, or sound effects more than course content, classroom discussion, or effective communication is a pitfall of PowerPoint presentation.

Third, McFedries, (2001) points out that the default bulleted format of the text promotes narrow-minded thinking and oversimplifies concepts that are perhaps far more complex than a list of ideas. Also, PowerPoint presentations eliminate the student's need to think critically about the information being presented. Processing information is an important step in the learning process, but it is often removed when PowerPoint is misused or overused.

Fourth, Miltenoff (2003) indicates that teachers do not need to write information on the blackboard, but just click the mouse. Therefore, it is very easy for teachers to give too much information in one class, which can difficult for learners to comprehend. What's more, learners are easily overwhelmed with a large amount of information given in the PowerPoint presentation (p. 67).

Finally, Boyle (1997) warns that technology such as PowerPoint is a mixed blessing. It helps teachers communicate information more quickly, but do not necessarily help them analyze whether or not information is accurate, relevant, or current. The more information they have, the more important it becomes to learn critical analysis, visual literacy, and information literacy skills (p. 24) but PowerPoint presentations don't always comply with this.

\section{Research Questions}

This study was developed on the following research questions:

- What do the participant learners perceive about the use of PowerPoint presentations in English classroom instruction at Preparatory Year Programme?

- Does the PowerPoint presentation contribute to better learning and result compared to traditional oral presentation with teacher writing on the board?

\section{Purpose of the Research}

The perception by both educators and non-educators alike is that PowerPoint presentations can improve the efficiency of English language teaching. The purpose of this research was to determine whether this study conforms to this concept. Moreover, the researcher has been an instructor at the PYP and has thought much about imparting the best classroom instruction and found PowerPoint Presentations as an effective technique to achieve the goals envisaged in the curriculum and course syllabus in the context of Arab English language learners' needs.

\section{Background of the Study}

More recently, the knowledge of English has been considered as one of the factors that can affect technology use in developing countries. English is considered as the dominant language of technology and computer (Albirini, 2006) because "instructions, messages, and internet texts are generally in some variant of the English language" (Navdal, 2007, p. 1113). Also, English is the most commonly used language among ten top languages exploited for communication and interaction via the internet (Internet World Stats, 2010) and almost two-third of websites on the internet are in English (Global Internet Statistics, 2010). As a result of this, there is a boom for English language classroom instruction on a global scale especially in the Arab world.

This study was conducted at the Preparatory Year Programme (PYP) at Jazan University, Saudi Arabia. The majority of the newly admitted learners join the PYP as part of the college degree curriculum, which aims to prepare learners for their undergraduate studies. The duration of the PYP is one academic year, divided into two semesters, as well as a summer session, if necessary. Improving learners' English language proficiency is one of the objectives of PYP and English is the major component of the programme. In addition to English, learners learn computer skills, mathematics, communication skills, and health and physical education, in order to cope with the English-medium studies at university level.

\section{The Classroom Setting}

The classrooms are equipped with interactive smart boards and projectors. Each instructor is provided with a laptop. The English course material includes New Headway Plus- Student's Book, Work Book, and Teachers' Book. The methodology asks for the integration of four skills. 
The course materials such as New Headway- Plus, Intermediate Learners' Book, Work Book etc., were scanned and converted to PDF files. Then slides on PowerPoint were prepared with relevant extracts and exercises from the PDF files according to the teaching techniques given in the teachers' book. Slides were prepared to teach grammar, vocabulary, reading, listening and writing. The teaching procedure is strictly adhered to the methodology and approaches suggested in the course book and teachers' book. Listening audio was inserted to the slides with corresponding exercises. Animation added to sustaining the interest of the learners. A common practice in PowerPoint presentation is that a single slide is filled with texts and the instructor reading from that. Contrary to this practice, at a time one specific and appropriate point of the lesson appeared on the screen giving chance for the learners to read and understand the tasks, exercises etc. Usually for a unit of the course material 25 to 30 slides were prepared. The preparation of slides was no easy task and it took hours to prepare the slides suiting the demands of the lesson. The encouragement and consolation for such hard work is the fruitful engagement of the learners throughout the lesson and effective classroom management with all learners showing much interest and enthusiasm.

\section{Significance of the Research}

The number of the researches investigating the effects of PowerPoint presentations in the English language learning classrooms has hitherto been limited. As for the realm of education in general, several research have been conducted and the results indicate their support for the effectiveness of PowerPoint presentations. Especially, Jazan University which is a recently founded university and in its initial stages, no such studies have so far been undertaken in the best of my knowledge. It is expected that the current study would contribute to the previous evaluations of the proponents of the PowerPoint presentations and to the improvement and effectiveness of English classroom instruction at the university.

\section{Methodology}

In order to answer the research questions of the study a survey was conducted on 50 learners who attended English lessons with PowerPoint presentation for one of the two semesters of the academic session 2011-2012. Fifteen (15) statements based on a five point Likert-scale ranging from 1 (strongly disagree) to 5 (strongly agree) was employed to examine learner perceptions about the pedagogical use of PowerPoint presentations in English language classroom instruction. Some negative statements were included in the Likert- scale statements to ensure that the participants really read understand the statements and mark their responses accordingly. Also the end of semester exam results of two classes of the same level, one where PowerPoint was used and the other with traditional oral presentation with teacher writing on the board, were analyzed to confirm the effectiveness of PowerPoint presentation compared to traditional oral presentation with teacher writing on white- board with markers. Also, relevant literature on the topic was reviewed. Thus this study is a both qualitative and quantitative.

\section{The Participants}

The participants of the study were one class of 50 arts and humanities male learners in the age group of 18-20, studying English at the Preparatory Year Programme at Jazan University, KSA. These participants were exposed to PowerPoint slides and PowerPoint presentations regularly during one semester of their course of study by the researcher. Therefore, to investigate the learners' perceptions about the effect of PowerPoint presentations, the selection of these core group learners was of great importance to the study.

\section{The Survey Results}

The questionnaire was constructed to find out learners' perceptions about the effectiveness PowerPoint presentations in terms of entertainment, information, understanding, organization, and helpfulness in English classroom instruction. The responses given by the participants are rated according to the following scale: SA (Strongly Agree), A (Agree), U (Undecided), D (Disagree) and SD (Strongly Disagree).

The results show that the majority of learners prefer PowerPoint presentations over the traditional methods of lecture delivery and likely have positive attitudes towards the use of PowerPoint presentation in English language classroom instruction. With mean score falling at 4.4 on a 5-point scale of the responses of $94 \%$ of the participants, it appears that the participants have a positive attitude toward PowerPoint presentations in their lectures. Only $6 \%$ of the participants were unsure of or in disagreement with the statements which express positive attitudes towards PowerPoint presentations. Besides, learners reported that PowerPoint presentations could be more beneficial for their English learning and examination review and they were likely to disagree that they preferred the lectures without PowerPoint presentations. The findings of the participants' attitudes towards PowerPoint presentations are summarized in Table 1. 
Table 1. Calculation of mean on likert - scale statements of the survey on learner perceptions about the use of PowerPoint presentation in the classroom instruction

(Scale of 1-5, higher score $=$ more agreeable to the statement)

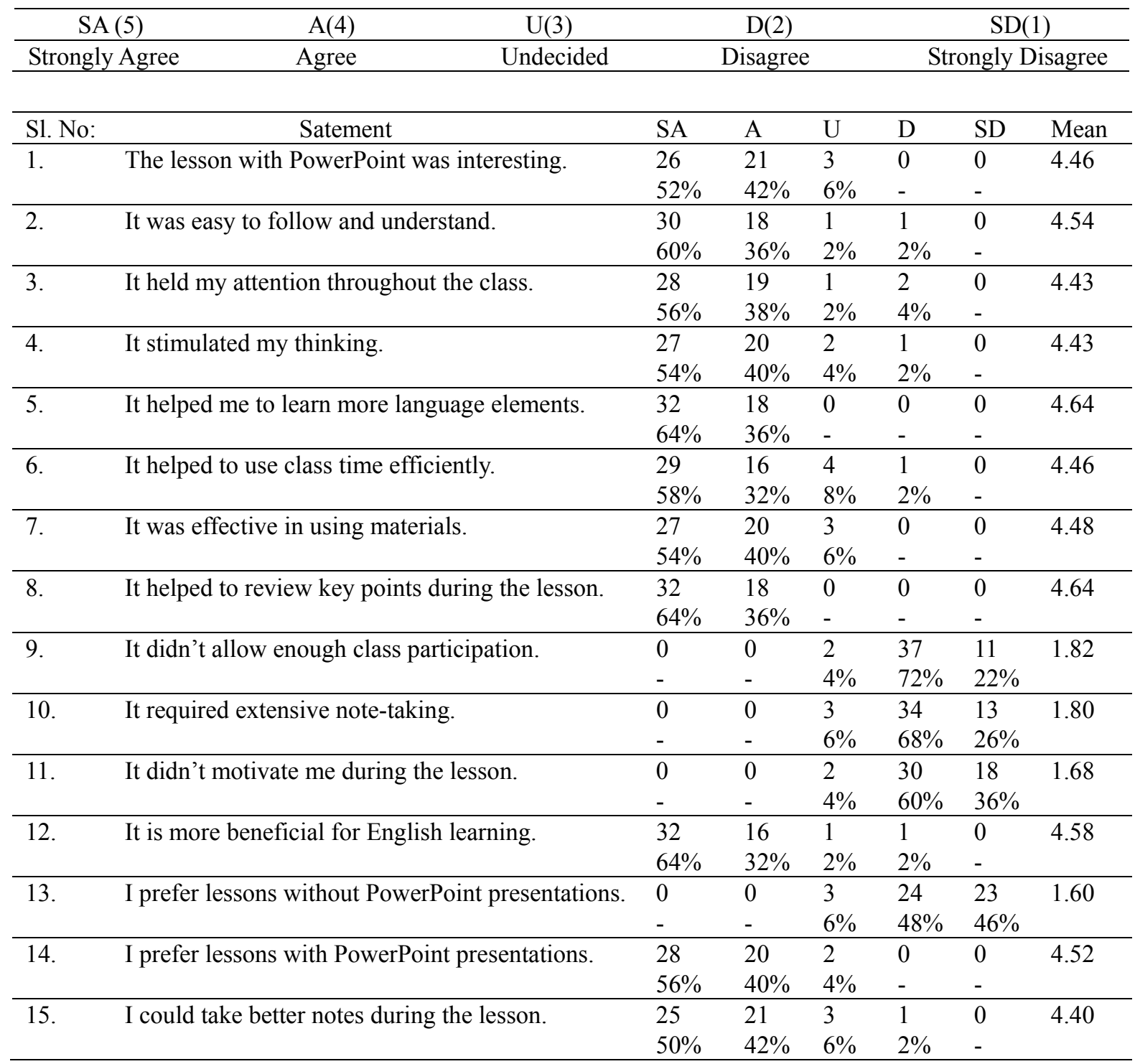

\section{Result Analysis of Learner Performance at End of Semester Exam}

Apart from the questionnaire survey, the summary of end of semester exam result of two sections of English classes of the same level, one where PowerPoint was used and the other with traditional oral presentation with teacher writing on the board, was analyzed to confirm the effectiveness of PowerPoint presentation compared to traditional oral presentation with teacher writing on white- board with markers. The test results show that learners who were taught with the aid of PowerPoint presentations fared better at the exam compared to the learners who were taught in the conventional oral presentations with white board and marker pens.

The summary of end of semester exam of two classes at the same level is displayed in Table 2 (a) \& (b).

Table 2 (a).

\begin{tabular}{lcccccc}
\hline Letter Grade & A & B & C & D & F \\
\hline Marks & Above 90 & $80-89$ & $70-79$ & $60-69$ & Below 60 & Total \\
\hline No: of Learners & 05 & 11 & 15 & 14 & 05 & 50 \\
\hline
\end{tabular}


Table 2 (b).

\begin{tabular}{lcccccc}
\hline Letter Grade & A & B & C & D & F & \\
\hline Marks & Above 90 & $80-89$ & $70-79$ & $60-69$ & Below 60 & Total \\
\hline No: of Learners & 04 & 03 & 12 & 21 & 10 & 50 \\
\hline
\end{tabular}

Table 2 (a) represents the details of letter grades and marks of learners who were taught using the PowerPoint presentations and (b) represents learners who were taught in traditional oral lecture and conventional white board on which instructors wrote with marker pens. The performance of learners who were taught with PowerPoint presentations are clearly found to be better than those learners who weren't taught with PowerPoint. Table 2 (a) indicates a uniform distribution of marks and grades. Moreover, more learners obtained higher grades in Table 2 (a) than those in Table 2 (b). It is evident from the tables that PowerPoint presentations have great impact on the performance of learners in tests and exams. Thus the effect of PowerPoint presentations in English classroom instruction is undoubtedly confirmed with these result summary analyses.

\section{Discussion}

The learner responses to the statements in survey questionnaire clearly indicate that in comparison to the conventional classroom instruction without PowerPoint presentations, learners preferred smart classrooms with PowerPoint presentations and they seemed to have positive attitudes towards PowerPoint presentations as they facilitate better learning and better performance at tests and examinations. Findings of this study conforms to the results of earlier studies of Cockburn and Matthew, 2006; Apperson et al., 2006; Corbeil, G., 2007; Savoy et al., 2009; etc and thus it is obvious that PowerPoint presentations can improve the efficiency of English language classroom instruction.

PowerPoint is a successful token of today's advanced technology, which learners warmly welcomed as it enhanced and enriched their English language learning experience. The lesson with PowerPoint was interesting holding their attention throughout the lessons. Further they followed and understood the lessons with enough class participation. PowerPoint presentations motivated the learners and stimulated their thinking. The learners believe that these presentations used the class-time efficiently and made use of learning materials effectively. The learners particularly considered the easy revision and review aspects of PowerPoint presentation more valuable. Thus it becomes clear that PowerPoint is an ideal tool for teaching and learning the English language. In addition, PowerPoint enhances the effectiveness of teacher presentations by highlighting keywords in the presentation, and displaying pictures and diagrams. The goal of the teacher is to create PowerPoint presentations that communicate messages effectively.

Due to the constraint of time, convenience, and relevant resources, the study was solely based on the learners' perceptions to investigate the efficacy of PowerPoint presentations on student learning. Further survey could be carried out among instructors and lecturers at the university to find out their motivation and attitude towards using technology and making use of the smart class set up to teach English language. It is also possible to identify reasons why most instructors and lectures initiate in the use of technology in their classrooms. Only after getting lecturers' opinions, reactions, and feedback would the scenario be complete. Then, it would be possible to see if there is a match or mismatch between the teachers and the learners.

\section{Conclusion}

The feedback from the participants in this study provided some suggestions on pedagogical changes that can be made. Almost all the learners responded positively towards the idea of using PowerPoint in English language classroom. Most important of all, it is hoped that the study could raise the awareness of PowerPoint presentation as a powerful pedagogical tool in the English classroom instruction, among language teachers, instructors, lecturers and educators. Teachers should take into consideration how learners like to learn and understand the learners' learning needs. Educational technology is playing an important role in the English language classrooms in the context of globalization and as a result of the emergence of English as a global language. As such instructors cannot ignore educational technology altogether. However, it does not mean that instructors should be totally dependent on educational technology but they can incorporate the use of technology to teach as a way to add variety into classroom procedures so learners get encouraged and motivated and do not get bored. It could be a form of motivation for the learners and also the teachers themselves.

\section{References}

Albirini, A. (2006). Teachers' attitudes toward information and communication technologies: The case of Syrian 
EFL teachers. Computers \& Education, 47(4), 373-398. http://dx.doi.org/10.1016/j.compedu.2004.10.013

Apperson, J. M., Laws, E. L., \& Scepansky, J. A. (2008, January). An assessment of student preferences for PowerPoint presentation structure in undergraduate courses. Computer \& Education, 50(1), 148-153.

Boyle, T. (1997). Design for multimedia learning (p. 24). London: Prentice Hall.

Cashman, T. J., \& Shelly, G. B. (2000). Microsoft Office 2000: Brief concepts and techniques (pp. 15-17). America: An International Thomson Publishing Company.

Catherina, F. (2006). Beyond presentation:Using PowerPoint as an effective instructional tool. Gifted Child Today, 4.

Cockburn, T., \& Matthew, A. (2006). Lecturing law with Powerpoint : what is the point? ELaw Journal, 13(1), 113-140. Retrieved on July $17, \quad 2011$ from https://elaw.murdoch.edu.au/archives/issues/2006/1/eLaw_Cockburn_13_2006_07.pdf

Corbeil, G. (2007). Can PowerPoint Presentations Effectively Replace Textbooks and Blackboards for Teaching Grammar? Do Learners Find Them an Effective Learning Tool?

Coulthard, G. J., \& Hutchinson, S. E. (1996). Microsoft PowerPoint 7.0 for Windows 95 (5, 7-8, 90, 95, 99-100, 124-125, 131-132, 158-159, 163-164.). America: Tom Casson. http://dx.doi.org/10.1187/cbe.04-06-0048

Fisher, D. L. (1998). Using PowerPoint for ESL teaching. Retrieved March 10, 2008, from http://iteslj.org/Techniques/Fisher-PowerPoint.html

Fisher, D. L. (2003). Motivation as a contributing factor in second language acquisition. The Internet TESL Journal, IX(4). Retrieved 20 May 2006 from http://iteslj.org/Techniques/Fisher-PowerPoint.html

Gaskins, R. (1984, August). Sample Product Proposal: Presentation Graphics for Overhead Projection. Retrieved on July 16, 2011 from http://www.gbuwizards.com/files/gaskins-original-powerpoint-proposal.pdf

Global Reach, Global Internet statistics (by Language): Sources \& references. Retrieved from http://global-reach.biz/globstats/refs.php3

Internet World Stats. Internet Usage Statistics- Big Picture: World Internet users and population stats. (2009). Retrieved June 2010 from http://www.internetworldstats.com/stats.htm

Keefe, D. D., \& Willett, J. D. A Case for PowerPoint as a Faculty Authoring System. Cell Biol Educ, 2004 Fall, 3(3), 156-158. http://dx.doi.org/10.1187/cbe.04-06-0046

Lanius, C. (2004). Points of View: PowerPoint in the Classroom: PowerPoint, Not Your Grandmother's Presentations, but Is it Evil? Cell Biol Educ, Fall 2004, 3, 158-160. http://dx.doi.org/10.1187/cbe.04-06-0047

McDonald, K. Examining PowerPointlessness. Cell Biol Educ, 2004 Fall, 3(3), 160-161.

McFedries P. (2001). The word spy. Retrieved 6 May, 2012 from http://www.wordspy.com

Miltenoff, P. (2003). Teaching with technology: Multimedia and interactivity in social science education. Multimedia Schools, 67, 120.

Navdal, F. (2007). Home-PC usage and achievement in English. Computers \& Education, 49(4), 1112-121. http://dx.doi.org/10.1016/j.compedu.2006.01.003

Roblyer, M. D. (2003, December 12). Integrating educational technology into teaching (3rd ed.). The United States: Jeffery W. Johnston. 167, 179.

Savoy, A., Proctor, R. W., \& Salvendy, G. (2009, May). Information retention from PowerPointTM and $\begin{array}{lllll}\text { traditional lectures. } & \text { Computer } \& \quad \text { Education, } & 52(4), & 858-867 .\end{array}$ http://dx.doi.org/10.1016/j.compedu.2008.12.005

Schcolnik M., \& Kol, S. (1999). Using Presentation Software to Enhance Language Learning. The Internet TESL Journal, 5(3). Retrieved 3 September 2005 from http://iteslj.org/Techniques/Schcolnik-PresSoft.html

Szaboa, A., \& Hastings, N. (2000). Using IT in the undergraduate classroom: Should we replace the blackboard with PowerPoint? Computers and Education, 32.

Towndrow, P. A., \& Vallance, M. (2004). Using IT in the Language Classroom: A Guide for Teachers and Learners in Asia (3rd edition). Singapore: Pearson Education South Asia Pte Ltd.

Tufte, E. (2003). Powerpoint Is Evil: Power Corrupts. PowerPoint Corrupts Absolutely (2003) by Edward Tufte. 
Voss, D. PowerPoint in the Classroom; Is It Really Necessary? Cell Biol Educ, 2004 Fall, 3(3), 155-156. http://dx.doi.org/10.1187/cbe.04-06-0045

\section{Author}

Abraham Oommen: Holds M.A., B.Ed., Cert. TESOL (Trinity College London) and is currently working as an Instructor of English at Jazan University, Gizan, Saudi Arabia. Has extensive teaching experience in Oman with MoE and at universities in Saudi Arabia (King Saud University), Ethiopia (Samara University) and England (Sussex University, Brighton). The field of research is 'teaching English as a global language at the tertiary level education'. 